\title{
Multikulturalisme dan Politik Anti Kekerasan
}

Oleh

\section{Heru Nugroho ${ }^{1}$}

\begin{abstract}
Abstrak
Multikulturalisme dan politik anti kekerasan di Indonesia menghadapi kondisi problematis saat ini, pengalaman negara mengelola perbedaan tidak berbading lurus dengan kondisi lapangan yang menunjukkan meningkatnya konflik horizontal. Kasus kekerasan antar etnis dan umat beragaman di Yogyakarta yang terjadi di pertengahan tahun 2014 ini telah menyentak kita bahwa multikulturalisme dan politik anti kekerasan bukanlah proyek temporer negara. Melainkan sebuah pemahaman dan cara berpikir yang perlu dikembangkan terus-menerus oleh semua pihak, sehingga multikulturalisme sebagai filosofi yang mengarahkan semua pihak agar mau saling mendengar dan memahami satu sama lain, tanpa harus menanggalkan prinsip dan keyakinan pribadinya. Revitalisasi dan penegakan filosofi multikulturalisme menjadi rujukan untuk melakukan penguatan peran politik rakyat di hadapan negara, membudayakan diskusi publik dalam proses pengambilan dan penentuan kebijakan, optimalisasi peran dan fungsi institusi lokal sebagai instrumen resolusi konflik dan negara harus mampu menjadi katalisator dalam pemberian peran ekonomi politik. Adapun hasil akhirnya diharapkan warga yang heterogen bisa hidup bersama-sama meskipun berbeda etnis, agama dan ras, sehingga mereka dapat saling menghormati dan memunculkan sikap toleransi.
\end{abstract}

Kata kunci: multikulturalisme, politik anti kekerasan, revitalisasi

\begin{abstract}
Multiculturalism and anti-violence politic in Indonesia are facing a problematic condition recently; the state's experience on the management of difference is not similar to the reality that shows the increasing amounts of horizontal conflicts. The violence cases based on ethnic and religion showed that multiculturalism and anti-violence politic are not just a temporary state project, but a process of understanding and a way of thinking that needs to develop by every stake holders so that multiculturalism as a philosophy that can direct every people to listen and understand each other without sacrifice their personal principles and beliefs. Revitalization and establishment of multiculturalism philosophy become the reference to reinforce the political role of people against the state, to promote public discussion in the decision making process, optimization on the role of local institution as an instrument of conflict resolution and state has to be able to become a catalyst on the distribution of economy and politic. As a result, heterogeneity of citizens can live together despite the difference of ethnic, religion and race so they can respect each other and raise the tolerance attitude.
\end{abstract}

Keywords: multiculturalism, anti-violence politic, revitalization

\footnotetext{
${ }^{1}$ Heru Nugroho adalah Guru Besar pada Departemen Sosiologi, Fisipol UGM.
} 


\section{A. Pendahuluan}

Di tengah-tengah hingar bingarnya para calon presiden dan wakilnya mempersiapkan diri untuk pelaksanaan pemilu presiden Indonesia 2014, masyarakat Yogyakarta tiba-tiba dikejutkan oleh suatu peristiwa kekerasan berbau SARA. Sekelompok orang yang tidak dikenal melakukan aksi anarkisme terhadap sekelompok warga yang sedang melakukan aktivitas peribadatan agama Katolik di rumahnya. Kejadian ini tepatnya di Kelurahan Sukoharjo, Kecamatan Ngaglik, Kabupaten Sleman (28/5/2014). Selang beberapa hari kemudian massa yang beringas melakukan aksi brutal berupa perusakan tempat ibadah agama Kristen di Kelurahan Pangukan, Kecamatan Tridadi, Kabupaten Sleman (1/6/2014). Akibat aksi kekerasan yang dilakukan oleh orang-orang yang tidak bertanggung jawab ini, beberapa orang mengalami luka yang cukup parah, bangunan rumah dan tempat peribadatan yang hancur serta adanya seorang jurnalis dari stasiun televisi Kompas TV yang luka dan dirampas kameranya ketika sedang meliput peristiwa tersebut, serta situasi sosial yang tidak kondusif untuk terwujudnya keberagaman keyakinan.

Aksi-aksi brutal, diskriminatif dan anarkis yang memakan korban jiwa, harta dan benda nampaknya semakin marak terjadi di tanah air sejalan dengan demokratisasi. Ilustrasi di atas hanyalah dua kejadian dari banyak kejadian yang berlangsung di negara ini selama pasca reformasi. Sebut saja misalnya aksi kekerasan berupa penyerangan dan pembunuhan terhadap pengikut aliran Ahmadiyah dan pengikut Syiah yang disertai dengan penghancuran tempat ibadah dan tempat tinggalnya. Begitu pula tindakan kekerasan massa yang terjadi di Propinsi Lampung, yaitu pembantaian, pembakaran rumah dan penghancuran tempat ibadah warga etnis Bali yang bermukim di sana. Dari kenyataan ini dapat dikatakan bahwa konflik horizontal yang berbau SARA bukanlah peristiwa yang asing, tetapi merupakan kejadian yang sering terjadi dan ada kecenderung akan terus berulang di negara yang memiliki kemajemukan ini kalau tidak ada kebijakan dari negara yang tegas.

Kejadian demi kejadian dalam setiap peristiwa konflik SARA tersebut selalu menimbulkan korban, namun negara sepertinya tidak hadir menuntaskan akar persoalan dari pangkal masalah konflik yang terjadi. Penyelesaian hanya bersifat permukaan, temporer dan tidak substansial. Penegakan hukum terkesan lemah, ragu-ragu dan tidak berdaya menghadapi gejolak konflik horizontal yang terjadi. Dalam masyarakat yang majemuk, keberadaan negara dirancang tidak untuk melindungi kaum minoritas, bukan pula membela keberadaan kelompok mayoritas. Eksistensi negara berkewajiban melindungi, mengayomi dan memberikan jaminan keamanan dan ketentraman bagi semua warga negara. Kehadiran institusi negara harus benar-benar dirasakan oleh setiap warganya ketika mereka dihadapkan pada satu situasi yang mengancam kedamaian, keselamatan dan hak-hak hidupnya yang dijamin oleh undangundang. Namun kenyataannya, manakala terjadi konflik yang berbau SARA kehadiran institusi negara terkesan terlambat, penyelesaian yang mengambang, dan solusi yang tidak jelas muaranya. Korban-korban akibat konflik horizontal sudah berjatuhan, banyak seminar dan diskusi dilakukan 
Jurnal Pemikiran Sosiologi Volume 2 No. 2, 2013

Multikulturalisme dan Politik Anti Kekerasan

Heru Nugroho

untuk memformulasi solusi penyelesaian, namun jawaban yang tegas atas pertanyaan "apakah formulasi solusi sudah sesuai dengan harapan?", jawaban selalu sama dari waktu ke waktu, yaitu jauh panggang dari api, artinya solusi yang ditawarkan tidak terbukti keampuhan dan efektivitasnya. Hal ini terbukti dari konflik yang selalu berulang dan terus terjadi. Semboyan "kebhinekaan" di Indonesia yang berarti mengakui adanya pluralitas dalam berbagai sendi kehidupan tidak dapat menjadi jaminan bahwa semua warga sudah terbebas dari ancaman dan intimidasi manakala mereka memiliki perbedaan dalam suatu sendi kehidupan, meskipun identitas yang dimiliki itu adalah hak azazi hidupnya.

Kebhinekaan di Indonesia bisa disepadankan dengansifat multikultur, sehingga paham Bhineka Tunggal Ika memiliki semangat multikulturalisme. Multikultur di Indonesia adalah bagian integral yang keberadaannya pada satu sisi merupakan satu kekayaan budaya, dan menjadi spesifikasi bangsa ini, tetapi pada sisi lain kalau tidak hati-hati di dalam pengelolaannya bisa mengarah pada terjadinya friksi sosial budaya dan berdampak pada terjadinya konflik horizontal yang mengarah pada terjadinya disintegrasi. Tidak dapat dipungkiri bahwasannya reformasi di Indonesia membawa dampak ikutan yang bersifat negatif. Dampak ikutan yang dimaksud berupa tingginya angka kejadian konflik horizontal yang terjadi di berbagai penjuru nusantara. Konflik yang terjadi pada tingkat lokal ini kalau dibiarkan berlarut-larut akan sangat mengganggu stabilitas di berbagai bidang, baik sosial, politik, ekonomi, maupun bidang lainnya, dan tentu saja yang lebih mengkhawatirkan dengan terjadinya konflik horizontal ini adalah disintegrasi bangsa. Untuk itu tulisan ini bertujuan menggarisbawahi agar persatuan dan kesatuan bangsa ini dapat tetap terjaga keutuhannya, dan masyarakat hidup dalam suasana yang nyaman maka dirasa perlu suatu upaya penguatan kembali kesadaran masyarakat tentang makna multikulturalisme dalam kehidupan berbangsa dan bernegara. Hal ini disebabkan karena paradigma multikulturalisme dipandang merupakan instrumen yang dapat merekatkan integrasi bangsa secara demokratis.

\section{B. Menguji Konsep Multikulturalisme}

Multikulturalisme adalah sebuah filosofi terkadang juga ditafsirkan sebagai ideologi, namun yang pasti itu adalah sebuah konsep tentang upaya yang menghendaki adanya persatuan dan berbagai kelompok kebudayaan yang saling berbeda dengan hak dan status sosial politik yang sama dalam masyarakat modern. Istilah multikulturalisme juga sering digunakan untuk menggambarkan kesatuan berbagai etnis masyarakat yang berbeda dalam suatu negara. Multikulturalisme bertentangan dengan monokulturalisme dan asimilasi yang telah menjadi norma dalam paradigma negara bangsa (nation-state) sejak awal abad ke 19 (Neil Bissondath, 2002). Monokulturalisme menghendaki adanya kesatuan budaya secara nomatif, sementara asimilasi adalah timbulnya keinginan untuk bersatu antara dua atau lebih kebudayaan yang berbeda dengan cara mengurangi perbedaan-perbedaan sehingga tercipta sebuah kebudayaan baru. Jadi multikulturalisme adalah suatu filosofi yang 
Jurnal Pemikiran Sosiologi Volume 2 No. 2, 2013

Multikulturalisme dan Politik Anti Kekerasan

Heru Nugroho

mengarahkan semua pihak agar mau saling mendengar dan memahami satu sama lain, tanpa harus menanggalkan prinsip dan keyakinan pribadinya. Dengan penegakan filosofi multikulturalisme ini maka diharapkan warga suatu negara yang heterogen bisa hidup bersamasama meskipun berbeda etnis, agama dan ras, sehingga mereka akan dapat saling menghormati dan muncul sikap toleransi (Bond, 2006).

Secara metodologis politik multikulturalisme menawarkan kesetaraan bagi setiap anggota masyarakat dalam hal hak-hak kewarganegaraan dengan memberikan kesempatan bagi setiap kelompok masyarakat mengidentifikasikan dirinya masing-masing. Dengan kata lain, politik multikulturalisme mengakomodasi sekaligus dua hal yang selama ini dipertentangkan yaitu kesetaraan dan perbedaan. Gagasan ini dianggap mampu meredam konflik vertikal dan horisontal yang terjadi dalam masyarakat di negara-negara dengan tingkat heterogenitas tinggi, akibat adanya tuntutan pengakuan atas keberadaan dan keunikan budaya kelompok etnis dalam masyarakat tersebut. Dengan demikian memberikan keleluasaan bagi berbagai identitas kelompok untuk melaksanakan kehidupannya secara lebih otonom.

Memahami multikulturalisme membutuhkan pemahaman yang lebih arif bagi konsep-konsep di dalamnya. Pertama, konsep keragaman dalam masyarakat multikultural tidak hanya berlaku untuk identitas etnis atau kesukuan, melainkan juga bagi identitas lainnya seperti ras, kelas, gender dan agama. Masing-masing kelompok dalam masyarakat berhak mengidentifikasi dirinya dengan perangkatperangkat yang membentuk identitas tersebut, apakah bahasa, sikap, nilai praktek politik dan sebagainya. Kedua, sebagai implikasi pemahaman di atas maka kultur-kultur kemudian tidak lagi dipahami sebagai produk jadi atau hasil aktivitas manusia. Kultur harus dipahami sebagai bentuk proses kontinum aktivitas dan dinamika anggota kelompoknya. Dalam masyarakat multikultural, nilai kultural ini akan saling berinteraksi dan melengkapi satu sama lain dengan mendasarkan diri pada kesetaraan dan toleransi (Parekh, 2001). Istilah multikulturalisme mengandung tiga komponen, yakni terkait dengan kebudayaan, konsep ini menunjuk kepada pluralitas kebudayaan dan cara tertentu untuk merespon pluralitas itu. Oleh karena itu, multikulturalisme bukanlah doktrin politik pragmatik melainkan sebagai cara pandang kehidupan manusia. Karena hampir semua negara di dunia tersusun dari aneka ragam kebudayaan, artinya perbedaan menjadi asasnya, dan gerakan manusia dari satu tempat ke tempat lain di muka bumi semakin intensif maka multikulturalisme itu harus diterjemahkan kedalam kebijakan multikultural yaitu sebagai politik pengelolaan perbedaan kebudayaan warga negara.

Ada tiga model kebijakan multikultural negara untuk menghadapi keanekaragaman etnis, suku, kelas, gender, agama dan lain- lain. Pertama, model yang mengedepankan nasionalitas. Nasionalitas adalah sosok baru yang dibangun bersama tanpa memperhatikan aneka ragam suku, bangsa, agama dan bahasa, dan nasionalisme bekerja sebagai perekat integrasi. Dalam kebijakan ini setiap orang, bukan kolektif, berhak untuk dilindungi negara sebagai warga negara. Model ini dipandang sebagai penghancur akar kebudayaan etnik yang menjadi dasar pembentukan negara dan menjadikannya sebagaimasa lampau saja. Model kebijakan 
Jurnal Pemikiran Sosiologi Volume 2 No. 2, 2013

Multikulturalisme dan Politik Anti Kekerasan

Heru Nugroho

multikultural ini dikhawatirkan terjerumus ke dalam kekuasaan otoritarian karena kekuasaan untuk menentukan unsur-unsur integrasi nasional berada ditangan suatu kelompok elite tertentu. Kedua, model nasionalitas etnik, yang mendasarkan kesadaran kolektif etnik yang kuat yang landasannya adalah hubungan darah dan kekerabatan dengan para pendiri nasional (founders). Selain itu kesatuan bahasa juga merupakan ciri nasional etnik ini. Model ini dianggap sebagai model tertutup karena orang luar yang tidak memiliki sangkut paut hubungan darah dengan etnis pendiri nasional akan tersingkir dan diperlakukan sebagi orang asing. Ketiga, model multikultural etnik yang mengakui eksistensi dan hak-hak warga etnik secara kolektif. Dalam model ini keaneka ragaman menjadi realita yang harus diakui dan diakomodasi negara dan identitas serta asal usul warga negara diperhatikan.Isu-isu yang muncul karena penerapan kebijakan ini tidak hanya keanekaragaman kolektif dan etnik, tetapi juga isu mayoritas/minoritas, dominan tidak dominan. Persoalannya menjadi lebih kompleks lagi karena ternyata mayoritas tidak selalu berati dominan, karena berbagai kasus menunjukan bahwa minoritas justru dominan dalam ekonomi. Jika kekuasaan negara lemah karena prioritas kekuasaan dilimpahkan kepada keanekaragaman kolektif, sebagai konsekuensi pengakuan negara maka negara mungkin akan diramaikan konflik internal berkepanjangan yang pada gilirannya akan melemahkan negara itu sendiri (Poster, 1992).

Ada satu kelemahan dari filosofi multikulturalisme yang patut disoroti bila dikaitkan dengan upaya

2 Merujuk istilah Spivak, kelompok yang dipinggirkan disebut sebagai "sub-altern". Bisakah sub-altern ber- memperjuangkan hak-hak minoritas, khususnya kelompok minoritas itu adalah kaum perempuan. Ketika memperjuangkan hak minoritas (khususnya perempuan), wacana multikulturalisme dinilai tidak konsisten. Dalam filosofi multikulturalisme terlihat bahwa jaminan atas hak-hak kaum minoritas yang ditawarkan hanya berlaku di wilayah publik, belum di ruang privat dimana kaum perempuan kerap ditempatkan. Kondisi tersebut menegaskan hanya kelompok mayoritas yang bisa bersuara, sementara yang minoritas dimarjinalkan. Karena minoritas maka mereka dianggap tidak setara dan karena itu tidak perlu didengar (Spivak, 1987).2 Tidak hanya itu hak-haknya juga dibuat tidak sama bahkan ditindas jika bersuara. Disini terlihat bahwa multikulturalisme sebagai jawaban persoalan kebebasan dan pemenuhan diri perempuan sebagai kelompok yang termarginalkan belum nampak. Hal ini cukup beralasan karena hampir seluruh nilai yang berakar pada budaya (culture) bersifat sangat patriakis dan mensubordinasi perempuan, sehingga kebebasan menjalankan nilai kultural yang dianjurkan dalam multikulturalisme akan dijadikan pembenaran bagi praktek opresi terhadap perempuan.

Hal ini tentu saja menjadi paradoks bagi ide multikulturalisme. Multikulturalisme menawarkan kesetaraan bagi setiap anggota masyarakat untuk memperoleh hak-haknya dan memberi ruang setiap kelompok masyarakat mengidentifikasikan dirinya masing-masing. Persoalan akan muncul ketika identitas kelompok tidak memberi ruang bagi identitas gender dalam masyarakat.

bicara menjadi adagium yang selalu dilontarkan Spi-vak dalam berbagai tulisannya. 
Jurnal Pemikiran Sosiologi Volume 2 No. 2, 2013

Multikulturalisme dan Politik Anti Kekerasan

Heru Nugroho

Perempuan kehilangan akses untuk mendefinisikan nilai kelompok serta ekonomi dalam menjalankan kehidupannya sendiri di masyarakat. Dalam hal ini perempuan menjadi sangat dirugikan karena nilai dan praktek dalam kelompok mengabaikan unsur kesetaraan gender. Beberapa contoh diantaranya adalah soal poligami, kawin paksa, KDRT dan sebagainya. Praktek tersebut menjadi lazim dilakukan karena oleh kelompok diklaim sebagai bagian dan nilai identitas yang mereka anut. Dalam filosofi multikulturalisme klaim tersebut dimungkinkan karena ada jaminan bagi kelompok menjalankan kehidupannya sendiri. Bahkan otoritas negara sering kali tidak mampu mengintervensi dengan nilai-nilai universal seperti Hak Asasi Manusia (HAM), keadilan dan sebagainya, misalnya dalam hal kawin paksa yang menimpa seorang perempuan (Gad Borzilai, 2003).

Merujuk pada pemahaman di atas, muncul argumentasi politik pengakuan multikultur telah mengabaikan pentingnya distribusi ekonomi dan material yang menentukan basis hidup banyak orang, termasuk perempuan. Kondisi ini menandai "berkembangnya ketidaksetaraan ekonomi," sangatlah berbahaya dan beresiko untuk menyarankan bahwa pengenalan terhadap identitas personal ataupun kolektif sendiri dapat menciptakan tujuan bagi masyarakat yang adil karena ini dapat mengalihkan masyarakat dari pentingnya pemenuhan kebutuhan distribusi dan pengakuan. Hal ini merupakan inti dari tulisan Nancy Fraser di Jurnal New Left Review pada tahun1995. Tulisan ini segera menarik perhatian banyak pihak, dan memicu perdebatan lanjutan. Menurut Fraser teori tentang politik pengakuan yang banyak berkembang sekarang ini mudah sekali jatuh ke dalam jargon-jargon politik identitas (political identity) yang memang juga mudah sekali jatuh ke dalam fundamentalisme kultural (Frazer, 2003).

Begitu pula fenomena reformasi di Indonesia memunculkan eforia bagi tuntutan pengakuan dan otonomi atas identitas etnis dan kesukuan. Di satu sisi reformasi membuka ruang eksistensi bagi setiap identitas kultural yang selama ini diabaikan atas nama persatuan dan kesatuan nasional. Disisi lain hal ini akan tidak menguntungkan bagi kelompok minoritas (misal: perempuan). Mengapa demikian, karena kelompok perempuan akan semakin terpojok dengan nilai identitas kesukuan dan lokalitas yang sangat patriakis. Apa yang disebut dan dipahami sebagai nilai kultural masih sangat didominasi oleh kelompok masyarakat laki-laki, akibatnya identitas perempuan belum mendapat pengakuan sebagaimana identitas kelompok masyarakat lain dan perempuan tetap pada dalam struktur subordinasi kekuasaan laki-laki.

\section{Multikulturalisme di Indonesia}

Reformasi di Indonesia berdampak pada mengemukanya isu-isu politik kebudayaan dan kemudian berkembang sangat cepat. Multikulturalisme menjadi salah satu isu yang muncul kepermukaan karena dianggap mampu menjadi ideologi perekat baru integrasi bangsa. Integrasi nasional yang selama ini dibangun berdasarkan politik kebudayaan seragam dianggap tidak lagi relevan dengan kondisi dan semangat demokrasi global yang juga meningkat sejalan dengan reformasi tersebut. Desentralisasi kekuasaan dalam bentuk otonomi daerah 
Jurnal Pemikiran Sosiologi Volume 2 No. 2, 2013

Multikulturalisme dan Politik Anti Kekerasan

Heru Nugroho

semenjak 1999 adalah jawaban bagi tuntutan demokrasi tersebut. Namun desentralisasi sebagai keputusan politik nasional ternyata kemudian disadari tidak begitu produktif apabila dilihat dari kacamata integrasi nasional suatu bangsa besar yang isinya luar biasa beraneka ragam suku, agama, kondisi geografis, kemampuan ekonomi bahkan ras. Dimasa lalu, kekuatan pengikat keanekaragaman itu adalah politik sentralisasi yang berpusat pada kekuasaan pemerintah yang otoritarian. Pada masa kini apabila konsepsi multikulturalisme itu digarap lebih jauh, selain dari keanekaragaman di atas, juga persoalan mayoritas/minoritas, dominan/tidak dominan yang juga mengandung kompleksitas persoalan.

Di sisi lain, mutikulturalisme tak hanya di tandai oleh perubahan politik. Tetapi secara sosiologis beriringan terjadi kebangkitan pandangan postmodernisme dan neoliberalisme berdampak besar dalam kehidupan masyarakat, telah terjadi upaya penyeragaman pola interaksi dan gaya hidup di kota-kota besar di Indonesia mulai tahun 1990an. Postmodernisme seolah memperkuat arus relativisasi nilai-nilai dan despiritualisasi masyarakat kota. Kemudian neoliberalisme, berusaha menarik masyarakat ke arah pasar bebas pencandu barang-barang konsumsi, semakin

\footnotetext{
3 Kondisi ini ditandai dengan meredupnya ideologi dan paham yang lahir dari rasionalisme, neopositivisme dan ideologi seperti sosialisme, idealisme, patriotisme, dan lain-lain. Sedangkan karakter yang menonjol dari perubahan tersebut seperti yang dinyatakan oleh Foucault (1992), yakni pertama, subyektifitas manusia telah mati seiring dengan perubahan yang terjadi. Individu tak lagi memiliki kesadaran utuh, dan tidak memiliki tuntutan akan kebenaran. Kehidupannya dikuasai retorika mental, sandiwara kata dan penafsiran tanda. Manusia hanya berwacana, tanpa tanggungjawab terhadap apa yang dilakukan; kedua, Penafsiran terhadap realitas sebagai fiksi yang diciptakan oleh imaginasi
}

memperparah pendangkalan budaya dan membuat kian senjangnya pola interaksi dan gaya hidup masyarakat. Proses yang dialami masyarakat Indonesia saat ini, sebenarnya tidak terjadi secara mendadak, sejak 1960an masyarakat Barat dan kota-kota besar lain di dunia dipandang telah menjauhi alam modern. ${ }^{3}$

Selanjutnya dalam konteks Indonesia, filosofi multikulturalisme kemudian penting diterjemahkan kedalam kebijakan multikultural sebagai politik pengelolaan perbedaan kebudayaan dan kehidupan warga negara. Model kebijakan multikultural yang dikembangkan harus mampu meredam terjadinya sumbatan interaksi antar budaya dan tetap memperkokoh adanya persatuan dan kesatuan bangsa. Oleh karenanya, maka dalam revitalisasi nilai-nilai multikulturalisme di Indonesia harus dikedepankan tentang perlunya penguatan dan pemberdayaan kaum minoritas. Hak-hak kaum minoritas harus dilindungi, apalagi ketika berhadapan dengan kelompok mayoritas.

Seandainya kita melakukan dengar pendapat dari seluruh penduduk yang tersebar di seluruh Indonesia, baik yang berasal dari segala macam ras, suku, golongan maka akan diperoleh kecenderungan jawaban bahwa mereka sepakat untuk hidup berdampingan secara damai.

manusia. Baudrillard (1983) menyatakan realitas hanya simulacra yaitu citra tanpa hakikat. Citra tanpa hakikat kemudian disebarkan keseluruh dunia melalui media informasi. Jika realitas tidak ada, maka yang ada hanya memunculkan citra atau simulasi yang tak bermakna. Ketiga, nihilisme menguasai jiwa manusia, perasaan bahwa segalanya tidak bermakna. Nilai-nilai mengalami keruntuhan. Manusia hanya benda yang digerakkan kesadaran yang tidak utuh. Apa yang dilakukan tidak merupakan kehendaknya. Adapun makna subyektif diberikan ke setiap manusia dengan cara berbeda sesuai tuntutan keadaan. 
Jurnal Pemikiran Sosiologi Volume 2 No. 2, 2013

Multikulturalisme dan Politik Anti Kekerasan

Heru Nugroho

Semangat kemajemukan ini merupakan sebuah kredo yang indah yang pernah ada di bumi. Bahkan kalau diamati secara cermat, kemajemukan merupakan sifat asli masyarakat yang berada di kawasan Asia Tenggara pada umumnya dan di Indonesia pada khususnya. Kemajemukan memang merupakan produk budaya masyarakat di kawasan Asia Tenggara yang saat ini masuk ke proses untuk menuju ke pendewasaan politik demokrasi.

Kemajemukan yang dibingkai filosofi multikulturalisme akan membentuk suatu mozaik kebudayaan dan peradaban yang khas. Hanya saja perlu suatu upaya untuk mencegah terjadinya negasi terhadap spirit kemajemukan yang selama ini hidup di bumi indonesia agar tidak mengarah pada terjadinya disintegrasi. Pada masa Orde Baru dalam rangka menegakkan stabilitas politik, komponen komponen SARA yang berdimensi horisontal seperti suku, agama, ras dan komponen yang berdimensi vertikal seperti antar golongan (kaya VS miskin, penguasa VS rakyat) dipandang sebelah mata sebagai faktor-faktor disintegratif bangsa. SARA tidak pernah dipahami sebagai kekuatan sentrifugal dalam kesatuan bangsa, akibatnya terapi politik yang dilakukan oleh rezim adalah penyeragaman "budaya dan politik" dalam konteks stabilitas politik dibawah tekanan kekuasaan otoriter. Kebijakan politik seperti ini justru tidak menyelesaikan persoalan yang dipicu oleh kemajemukan, bahkan ada kecenderungan semakin menajam. Bahaya SARA yang dikonstruksikan melalui politik resmi dan sosialisasi melalui wacana elit politik, melembaga secara sosial hingga menjadi pengetahuan sehari-hari di kalangan orang awam bahwa keberagaman SARA adalah unsur pemecah bangsa. SARA tidak dipahami sebagai kenyataan sosial yang ada pada setiap masyarakat dan keberadaanya justru dapat mewujudkan demokrasi dan budaya. Akibatnya bagi orang awam melihat SARA sebagai hantu, sehingga mudah diprovokasi untuk konflik-konflik sosial dengan pemicu salah satunya atau beberapa komponennya.

Dari tiga model kebijakan multikultural yaitu model yang mengedepankan nasionalitas, model nasionalitas dan model kebijakan multikultural etnik yang telah dipaparkan diatas, diakui tidak satupun dan tiga model kebijakan itu cocok atau pas untuk diaplikasi di Indonesia. Namun tidak berarti bahwa penegakkan paradigma multikulturalisme tidak dapat dilakukan di Indonesia.

\section{Rekomendasi}

Revitalisasi filosofi multikulturalisme di Indonesia dapat dilakukan dengan merujuk pada beberapa alternatif cara sebagai berikut: Pertama, meskipun tiga model kebijakan multikultural yang telah dipaparkan di atas diakui kurang cocok atau pas untuk diaplikasikan di Indonesia, revitalisasi filosofi multikulturalisme tetap dapat dilakukan dengan cara mengurangi dominasi peran negara dalam proses politik agar tidak terjadi distorsi dalam wacana tentang SARA, baik di kalangan masyarakat maupun di kalangan elite politik. Kedua, harus terjadi penguatan peran politik rakyat di hadapan negara. Negara jangan sampai terlalu banyak mengintervensi dalam setiap pengambilan kebijakan, baik di tingkat pusat maupun daerah. Ketiga, dalam penentuan kebijakan maka terlebih dahulu harus dilakukan suatu aktifitas diskusi publik. Keputusan diambil dengan mengacu pada 
Jurnal Pemikiran Sosiologi Volume 2 No. 2, 2013

Multikulturalisme dan Politik Anti Kekerasan

Heru Nugroho

suara mayoritas yang ditetapkan pada saat diskusi publik di lakukan.

Keempat, optimalisasi fungsi dan peran institusi lokal sebagai suatu alat dan media untuk resolusi manakala terjadi konflik harus terus ditingkatkan. Kelima, negara harus berfungsi sebagai katalisator dalam pemberian peran ekonomi politik yang seimbang pada setiap etnik/golongan di bumi Indonesia agar tidak terjadi disparitas sosial, politik, ekonomi antar etnis.

\section{E. Kesimpulan}

Salah satu ancaman bagi keutuhan Negara Kesatuan Republik Indonesia adalah terjadinya friksi yang mengarah pada konflik horizontal. Faktor penyebab terjadinya konflik ini salah satunya adalah karena kondisi bangsa Indonesia yang sangat multiheterogen hampir di segala bidang kehidupan. Untuk meminimalisir kemungkinan terjadinya konflik horizontal, salah satunya adalah melalui upaya revitalisasi dan implementasi filosofi multikulturalisme dalam kehidupan berbangsa dan bernegara, karena filosofi ini dianggap mampu mengakomodasi adanya perbedaan dan sikap toleransi di antara warga yang majemuk tanpa harus kehilangan identitas budayanya dari masing-masing entitas.

Merespon hal tersebut filosofi multikulturalisme perlu direvitalisasi dengan cara melakukan penguatan peran politik rakyat di hadapan negara, membudayakan diskusi publik ketika proses pengambilan dan penentuan kebijakan, mengoptimalkan peran dan fungsi institusi lokal sebagai instrumen resolusi konflik dan negara harus mampu menjadi katalisator dalam pemberian peran ekonomi politik yang seimbang kepada setiap etnis dan budaya.

Dengan cara inilah maka diharapkan paradigma multikulturalisme dapat menjadi filosofi dan ideologi masyarakat. Dengan itu maka harapan akan tegaknya harmonisasi sosial dapat terwujud, friksi yang mengarah pada konflik horizontal dapat dicegah dan politik nirkekerasan dapat dikedepankan, sehingga disintegrasi bangsa bisa dihindari.

\section{Daftar Pustaka}

Baudrillard, Jean. 1983, Simulations, Semiotext(e), USA.

Bond, Ross. 2006. "Belonging and Becoming: National Identity and Exclusion", Sociology, Vol. 4 (40)

Bissondath, Neil. 2002. Selling Illusions: The Myth of Multiculturalism, Toronto: Penguin.

Borzilai, Gad. 2003. Communities and Law: Politics and Cultures of Legal Identities. Michigan: University of Michigan Press.

Fraser, Nancy, 1995. "From Redistribution to Recognition? Dilemmas of Justice in a "PostSocialist" Age, New Left Review 212: 68-93.

Frazer, Nancy. 2003. The Radical Imagination: Between Redistribution and Recognition. Philadelpia, USA.

During, Simon. 1992, Foucault And Literature. New York, Routledge.

Morton, Stephen. 2003. Gayatri Chakravorty Spivak. New York: Routledge.

Parekh, Bikhu. 2001. Rethinking Multiculturalism. Harvard: Harvard University Press. 
Jurnal Pemikiran Sosiologi Volume 2 No. 2, 2013

Multikulturalisme dan Politik Anti Kekerasan

Heru Nugroho

Poster, Mark. 1992. "Postmodernity and the Politics of Multiculturalism: The Lyotard-Habermas Debate Over Socia l Theory", Modern Fiction Studies.

Spivak, Gayatri Chakravorty. 1987. In Other World: Essays in Cultural Politics. New York: Methuen 